\title{
Fragilities and potentialities in the training of nurse leaders
}

\author{
Fragilidades e potencialidades na formação de enfermeiros-líderes \\ Fragilidades y potencialidades en la formación de enfermeros lideres
}

\author{
Simone Coelho Amestoy ${ }^{\mathrm{a}, \mathrm{b}}$ \\ Letícia de Lima Trindade ${ }^{c}$ \\ Gilberto Tadeu Reis da Silvab \\ Maria Manuela Martins ${ }^{d}$ \\ Patrícia Alves Galhardo Varandab \\ Ises Adriana Reis dos Santos ${ }^{b}$
}

How to cite this article:

Amestoy SC, Trindade LL, Silva GTR,

Martins MM, Varanda PAG, Santos

IAR. Fragilities and potentialities in the training of nurse leaders. Rev Gaúcha Enferm. 2021;42(spe):e20200196. doi: https://doi.org/10.1590/19831447.2021 .20200196
Universidade Federal do Vale do São Francisco (UNIVASF), Colegiado de Enfermagem. Petrolina Pernambuco, Brasil.

- Universidade Federal da Bahia (UFBA), Programa de Pós-Graduação em Enfermagem. Salvador, Bahia Brasil.

c Universidade do Estado de Santa Catarina (UDESC). Chapecó, Santa Catarina, Brasil.

¿Escola Superior de Enfermagem do Porto (ESEP) Porto, Portugal.

\section{ABSTRACT}

Objective: To know the perception of nursing professors about the fragilities and potentialities in the training of nurse leaders. Method: Multiple case study, with a qualitative approach, performed with 36 nursing professors from a public university in the State of Bahia, Brazil. Data were collected through semi-structured interviews, interpreted in the light of Paulo Freire's theoretical framework and analyzed according to Thematic Analysis and the Nvivo ${ }^{\oplus} 11$ software.

Results: Were highlighted as fragilities the need to improve the transversality of leadership throughout graduation and teaching focused on the banking model. The potentialities refer to the insertion of the students in the practice scenarios, enabling the approximation with the nursing and multidisciplinary teams, the use of active methodologies and participation in research groups. Final considerations: Professors consider the importance of problematizing pedagogical practices and invest in methodological strategies capable of promoting the training of nurse leaders.

Keywords: Nursing. Leadership. Education, nursing. Health management. Education, higher.

\section{RESUMO}

Objetivo: Conhecer a percepção dos docentes de enfermagem acerca das fragilidades e potencialidades na formação de enfermeiroslíderes.

Método: Estudo de caso múltiplo, de abordagem qualitativa, realizado com 36 docentes de enfermagem de uma universidade pública do Estado da Bahia, Brasil. Os dados foram coletados por meio de entrevistas semiestruturadas, interpretados à luz do referencial teórico de Paulo Freire e analisados conforme a Análise Temática e do software Nvivo ${ }^{\oplus 11 .}$

Resultados: Destacaram-se como fragilidades a necessidade de aprimorar a transversalidade da liderança ao longo da graduação e o ensino voltado ao modelo bancário. As potencialidades referem-se à inserção dos discentes nos cenários de prática, possibilitando a aproximação com as equipes de enfermagem e multiprofissional, uso de metodologias ativas e participação em grupos de pesquisa. Considerações finais: 0s docentes consideram a importância de práticas pedagógicas problematizadoras e investem em estratégias metodológicas capazes de fomentar a formação de enfermeiros-líderes.

Palavras-chave: Enfermagem. Liderança. Educação em enfermagem. Gestão em saúde. Educação superior.

\section{RESUMEN}

Objetivo: Conocer la percepción de los profesores de enfermería sobre las debilidades y potencialidades en la formación de enfermeros líderes.

Método: Estudio de caso múltiple, con enfoque cualitativo, realizado con 36 profesores de enfermería de una universidad pública del Estado de Bahía, Brasil. Los datos se recopilaron mediante entrevistas semiestructuradas y se analizaron de acuerdo con el marco teórico de Paulo Freire, con la ayuda de Análisis temático y el software Nvivo ${ }^{\circledast 11 .}$

Resultados: Se destacaron como debilidades la necesidad de mejorar la transversalidad del liderazgo durante la graduación y la enseñanza centrada en el modelo bancario. Las potencialidades se refieren a la inserción de los estudiantes en los escenarios de práctica, posibilitando la aproximación con los equipos de enfermería y multidisciplinario, el uso de metodologías activas y la participación en grupos de investigación.

Consideraciones finales: Los docentes consideran la importancia de problematizar las prácticas pedagógicas e invierten en estrategias metodológicas capaces de promover la formación de enfermeros líderes.

Palabras clave: Enfermería. Liderazgo. Educación en enfermería. Gestión en salud. Educación superior. 


\section{口INTRODUCTION}

Nursing leadership represents a management competence, by which nurses seek to influence and motivate their team to achieve objectives and goals that favor meeting the demands of users ${ }^{(1)}$. The development of nurse leaders is reflected in a strategic objective that has a favorable impact on working relationships with the team, however health institutions lack programs that foster leadership ${ }^{(2-3)}$ and professionals that prioritize the healthcare management ${ }^{(4)}$.

Some health services have difficulties in providing quality care and lack nurses who have the knowledge, skills and attitudes to exercise leadership, in addition to collaborating constructively to meet the health needs of the population, as well as achieving institutional goals ${ }^{(5)}$. It is highlighted the important role of the nurse leader in care practice, both for the quality of care and for the performance of the teams. However, there is a need for greater investments in the training of nurse leaders ${ }^{(6)}$, as well as in the processes of continuing education, where these are problematized and more democratic, making efforts so that the professionals' voice and their needs are heard. This movement can not only empower professionals but also allow the perception that the manifestations emanating from words and work are materialized as action-reflection.

In order to meet these needs, nurses need to develop relational skills that will facilitate the management of conflicts, the people management and material supplies, as well as the clinical and managerial decision-making process ${ }^{(4)}$. Therefore, it is necessary to encourage the development of leadership even during the training process, so that future nurses can be more secure and able to exercise it.

The development of leadership potential during academic training and its permanent improvement in health services must be a premise, being this a concern shared by professors, students, managers and professionals inserted in practice ${ }^{(4)}$. Literature ${ }^{(4,7)}$ indicates that, in the teaching context, students have difficulties to understand leadership as part of education and/in practice, so that nursing education lacks a specific model for leadership development.

Other studies ${ }^{(8-10)}$ reinforce these concerns, highlighting the need to implement models and programs that promote the development of leaders.

Teaching practice needs to be supported by transformational processes, so that professors can use resources in order to stimulate students' critical capacity, autonomy and curiosity. A study ${ }^{(11)}$ carried out with nursing professors recognizes the need for changes in pedagogical practice, especially related to the discipline of nursing administration, in order to ensure dynamic and updated knowledge, with teaching-learning strategies effectively aimed at leadership development.

Such a transformation, if it occurred, would enable professors to act through the process of action-reflection, in full movement of pedagogical practice, to "want"the constitution of a critical, engaged and leader professional. In this way, there is an urgent need to involve educators and students, so that together they can transform the act of learning by reality, in an action that will make it possible to understand educational relationships as a process that promotes transformative actions, as well as a leadership that challenges and dare changes in training.

The formation of leaders in nursing needs to be discussed as a priority aspect in the academic environment and, for that, it is necessary the wide participation of professors as mediators and promoters of opportunities for students, so that they can, in addition to expanding their theoretical knowledge, exercise their leadership potential. Investigation ${ }^{(12)}$ with the aim of verifying the impact of teaching leadership in nursing, indicates that the theme is paramount, but it has not always been addressed in an integrated way in undergraduate nursing courses. In view of the above, it is considered urgent to provide learning scenarios and situations that enable the development of this competence by the nurse $\mathrm{e}^{(13)}$.

In order to strengthen the theoretical framework of the study, it was adopted Paulo Freire's conception ${ }^{(14)}$ as a reference, in view of the relevance of his ideas about teaching and leadership. According to the aforementioned author $r^{(14)}$, leadership, when dialogical, is not practiced in isolation and requires collective ideas so that it can, in fact, transform reality. It is strengthened through educational practice by signaling new directions, being democratic through participation and collective organization in debating the theoretical and practical methods of educational activities.

The adoption of teaching practices by professors that foster the perspective and the act of learning by reality, exercising together educator and educating, consciously, the exercise of dialogue, autonomy and the active participation of these subjects, enabling the favoring and the development of leadership in training scenario ${ }^{(4)}$, in addition to mitigating challenging situations and assisting in the creation of new teaching-learning opportunities.

Therefore, this investigation sought to answer the following guiding question: what is the perception of nursing professors about the fragilities and potentialities in the training 
of nurse leaders? In view of the above, the investigation aims to understand the perception of nursing professors about the fragilities and potentialities in the training of nurse leaders.

\section{METHODS}

The study of qualitative approach, of descriptive and exploratory type, performed at the School of Nursing of a public university in the State of Bahia, Brazil. It consists of the first School of Nursing for the training of nurses in the State in question, being a reference in the quality of teaching in the Northeast Region, both in undergraduate and graduate courses. The undergraduate course consists by 10 periods and aims to train nurses generalists, who are ethically committed to the quality of care and the principles of the Unified Health System.

For the definition of the participants, the inclusion criteria were: being an effective professor and having worked for at least one year in the Undergraduate Nursing Course. As for the exclusion criteria, professors who were on leave for any reason during the data collection period were excluded, those who showed no interest and did not provide a time for the interview, after three attempts and who did not meet the inclusion criteria.

It is worth mentioning that in the period of data collection, 68 permanent professors worked, from these 14 professors were excluded, for not having made available, time to conduct the interviews or showed interest in participating in the research, after three attempts. In addition to these, eight did not meet the inclusion criteria, five were on leave for qualification in stricto sensu graduate programs, one retired during the data collection period, two were on maternity leave and two on medical leave. After applying the exclusion criteria, 36 professors participated in the study.

Data collection took place from February to August 2017, through semi-structured interviews, carried out individually in a private room, in the study scenario, on dates and times scheduled according to the availability of each participant. It is important to mention that all interviewees expressed their agreement to participate in the study and signed the Free and Informed Consent Form (ICF).

The interviews were recorded and followed a pre-established script with guiding questions centered on the study theme. First, the professors answered questions related to sociodemographic characterization and afterwards, they were asked about their understanding about teaching leadership, adopted pedagogical practices, challenges and the positive aspects for the training of nurse leaders.

The participants were identified by the letter D (initial of the word docent), followed by an ordinal number corresponding to the order of the interviews, for example: D1, D2 ... D36, successively.

The data underwent subjectivist interpretation, according to the Thematic Analysis steps ${ }^{(15)}$, with the support of the NVivo ${ }^{\oplus 1} 1$ software. Thus, there was a fluctuating reading of the field material; the constitution of the corpus that refers to the studied universe and exhaustive reading of the material in all aspects provided in the script. The formulation and reformulation of hypotheses and objectives was an exploratory step that aimed at an exhaustive reading of the collected material. In this exploratory process, the researcher sought for significant expressions or words within the content of the statements. Finally, the results obtained were treated, from which two categories were constructed: "Fragilities in the teaching of leadership" and "Potentialities in the teaching of leadership", which were interpreted in the light of Freire's theoretical framework.

The ethical precepts of Resolution No. 466/2012 were followed, of the National Health Council, which regulates research with human beings, and the project received approval from the Research Ethics Committee (CAAE: 54719616.6.0000.5577/2016).

\section{RESULTS}

Participated in the study 36 professors of the Undergraduate Nursing Course, from whom, together, work in subjects from the first to the tenth semester. As for the participants characterization, the majority are female $(n=30)$, aged between 28 and 70 years old, average of 45 years old, training time from 20 to 43 years old, average of 23 years. As for professional improvement, professors with doctorates $(n=24)$ predominated, followed by masters $(n=08)$ and postdoctoral $(n=04)$. Following, the findings of the categories emerging from the analysis process are presented (Figure 1). 


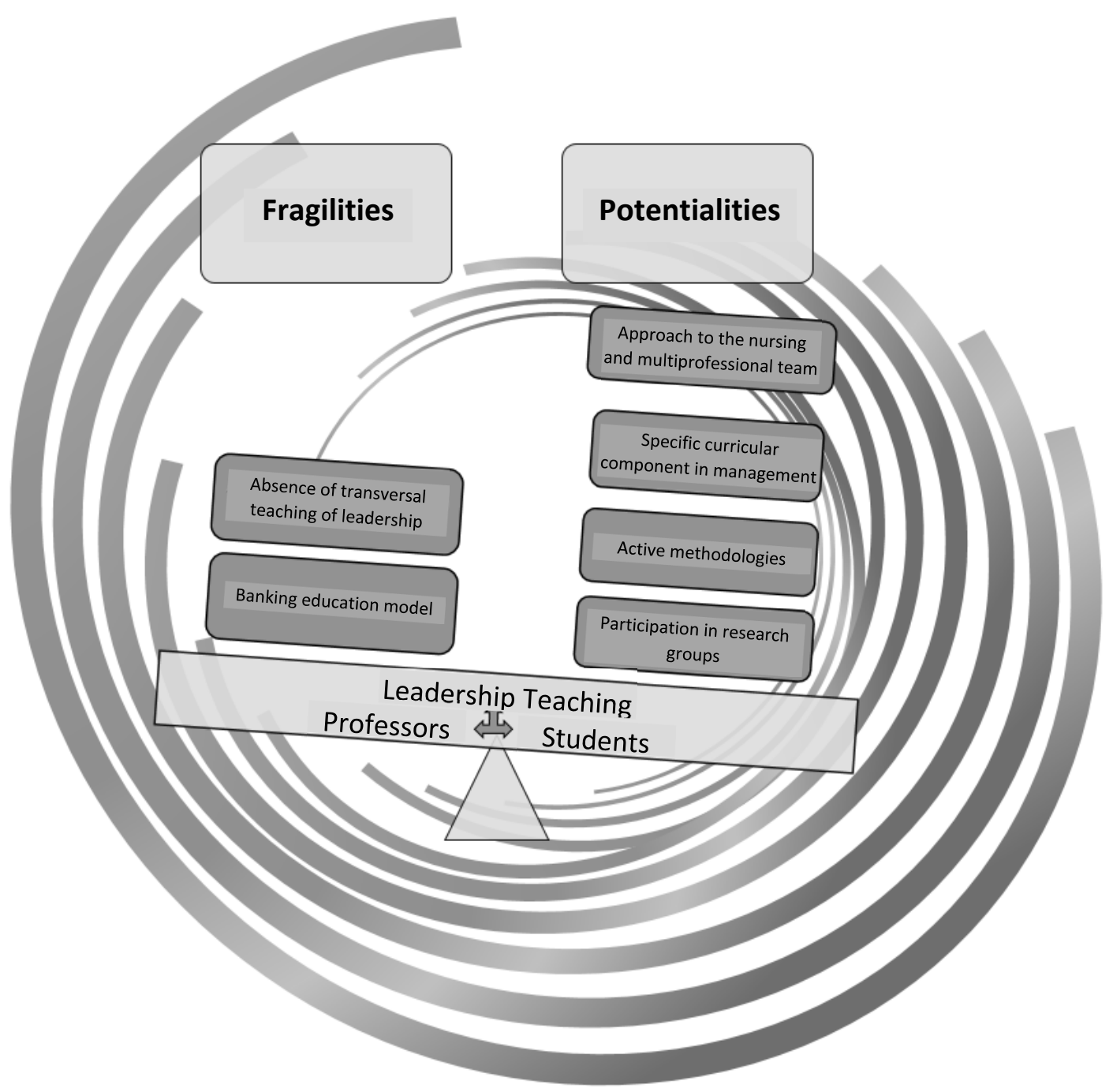

Figure 1 - Study categories

Source: The authors, 2020.

\section{Fragilities in the teaching of leadership}

In the professors' conception, the absence of transversal leadership education during nursing training, from the first semester to the tenth, represents a fragility. According to them, such content is restricted to the last periods of graduation, notably to the discipline that addresses the health services management.

Leadership teaching must take place from the first semester of the course. We realize that the student comes fragile in relation to leadership when he experiences urgency and emergency (D1).

The biggest fragility is this fragmentation, because leadership is a content of management and we know that management is transversal, it must happen from beginning to end. In all curricular components, we must somehow bring management content (D5).

Leadership is not a knowledge of a class, it is a transversal knowledge (D13).

We will discuss, within a pedagogical meeting with professors, how to make leadership a transversal manner. The fragility comes from this, because, when I don't think about it, I don't argue and I don't do it, I don't use it (D16). The leadership content should be transversal, because it is one of the functions, in the law of professional practice, that are exclusive to nurses. If he/she doesn't start working at the beginning of the training, he/she will probably have a harder time understanding this process (D18). 
[...] it could be transversal and treated in an explicit way that permeated all content (D33).

[...] you don't have to let the student get there in the ninth semester to work with him. I think that, since he enters the course, it has to be worked on (D35).

The statements also show evidence of the banking education model, characterized by classes centered on the figure of the professor, with little space for the students to participate, as shown in the following excerpts:

In higher education in general, there is hegemony of the banking model, it gives the impression that it is the professor who holds the knowledge and determines how he will pass it on and evaluates the student on the ability he has to decorate [...] it ends up not offering experience, which is fundamental for building leadership (D32).

One of the most evident fragilities regarding the teaching of leadership at graduation I believe that the classes are centered on the professor and not on the student (D25).

Professors are still very much in banking education, that the person goes and presents that and he/she charges that in the test. And that's how I think she teaches leadership. Cold knowledge, if I don't put those emotions, those feelings into practice, how am I going to train a person to have relative aspects for leadership? (D2).

It is very much in the parental model of teaching that we have to teach, and another has to learn. Expository classes or those that do not dialogue predominate, do not allow the other to have initiative and seek this position of leadership, of the person responsible for their learning (D22).

We are very theoretical, stuck to the pattern and replicating models. Nobody wants that anymore! Neither the undergraduate student (D26).

As for the main fragilities, difficulties were highlighted in offering the transversal teaching of leadership so that this competence could be developed during the training, in addition to maintaining educational practices still linked to banking education.

\section{Potentialities in the teaching of leadership}

The insertion of the students in the different practice scenarios and, therefore, their approximation with the nursing and multidisciplinary team, was pointed out as a potentiality, which adds value to the construction of the leader:
The course is extremely rich and diverse. The student has the possibility to work in several care stations: in the basic network, in the hospital network, in the classroom environment, which are spaces that have the possibility to work on aspects of leadership (D1).

The potentiality is the student's experience in the context of practice, which is the condition for identifying the different nursing leaders (D3).

Students start early in the field of practice. Relationships with different members of a multidisciplinary team are also factors that favor and influence this aspect of leadership (D21).

One potentiality is the insertion in practice and this issue of leadership posture, of having a good relationship with the nursing team, with the multiprofessional team itself (D34).

They also highlighted as potentialities the use of active methodologies, such as realistic simulations, problem situations, clinical cases, problematization of the reality.

\section{"[...] the problematization of the reality experienced by} these students in the scenario of care in urgencies and emergencies, are possibilities that help us to discuss the leadership aspects [...] in the practical situation itself as much as we are with them in laboratory practices and skills, in the classroom also with situations of clinical cases, problem situations, the professor needs to lead the students." (D1)

"I think the simulations are very interesting. Being simulations with problems, so I have the problem and the question of how a leader like you would solve [...] to use participatory, problematized methodologies and simulations more explicitly". (D16)

Another aspect highlighted in the interviews was the teaching promoted through a specific curricular component in management, in the researched scenario, called Health Systems and Services Management. According to the professors, this offers, in addition to a wide theoretical background, the possibility of evaluating practical issues that arouse the interest of undergraduates to the exercise of leadership.

When these students go to practice, now no longer due to components of assistance but management, they are able to apprehend the leadership role or not of these professionals (D1). 
About the potentialities in training, students have the privilege of having subjects that deal with management and the health system in a globalized way, which not all other courses offer (D4).

Making the student reflect on the situations, I think the strategy would be this, because this is not done in the classroom, it is more because of situations that we observe in the field and in practice, analyze the leadership and reflect (D34).

The participation in research groups that address the management theme was also mentioned as a potentiality, as it favors the structuring of the exercise of leadership in the training scenario.

$[\ldots$.$] the research group is a space where the student$ exercises more leadership. I'm the leader of the group, but a graduate student assists in coordination with am undergraduate student, so they need to make the whole group work, and a group to work is: articulation with people, arriving on time, frequency, care for the other, students are discussing projects, they are having the power of speech. I think it is very sharp the leadership of my students who participate in the research group (D36).

$[. .$.$] in the research group we are seeking to empower$ students to study interesting management issues, such as leadership, and we are opening a discipline in graduate school (D13).

According to the results obtained, the potentialities are mainly related to the approach to the nursing and multiprofessional team, to the teaching provided by professors in the curricular component that addresses the management theme and the active methodologies adopted. They also concern the participation of students in research groups, which stimulate their participation, autonomy, and proactivity.

\section{DISCUSSION}

It is noteworthy that training is one of the main foundations of leadership development, this way only the competent conduct of the teaching-learning process can support the necessary basis for the satisfactory performance of the nurse leader ${ }^{(16)}$ and identify the fragilities and potentialities can be a basic premise for the qualification of teaching this managerial competence in undergraduate nursing.

Regarding the fragilities that permeate the teaching of leadership, the need to ensure the transversality of the theme during the graduation has emerged. In the national scenario, a study ${ }^{(4)}$ analyzed the nurses' understanding of the teaching of leadership at graduation and its exercise in the hospital environment. The participants recognized as positive the theoretical support provided by nursing professors, but mentioned the need to include a transversal approach to leadership throughout undergraduate studies. A similar result was reported in a Jamaican study ${ }^{(17)}$ carried out with nursing students, which emphasized the importance of fostering leadership from the beginning of the undergraduate course. The transversal teaching of leadership consists of its approach throughout the course, being articulated in the curricular components, which will enable greater awareness of the students, as well as valuing their maturity to understand and exercise it, according to the experiences, knowledge and skills, consistent with the semester that the student is inserted. In this perspective, the leadership theme would be interwoven in the whole act of learning through the reality and experience. Such possibility, based on the conscious understanding of constructs of active participation, sensitive listening, autonomy, and dialogue.

The Management curriculum component has made efforts to foster pedagogical practices that contribute to the training of nurse leaders. The leadership consists of a specific content of this discipline, however it is also signaled, from the perspective of integration between the other curricular components, so that the theme is explored in a collective and articulated way, avoiding specific approaches, and enhancing their problematization, in addition to promoting greater interaction between professors and students.

Another fragility, also mentioned by the professors, is the maintenance of teaching geared towards the banking and bureaucratic model, centered on expositive classes. In the conception of the theoretical framework ${ }^{(14)}$, banking education consists of the deposit of educators' content in students, with no space for reflections or positions, which compromises the transformation of reality. In addition, a passive curriculum centered on expositive classes represents an impoverished pedagogical practice ${ }^{(18)}$.

In order to overcome these fragilities, it is suggested the teaching of leadership from an integrative education, bringing professors and students closer and integrating, in a creation and re-creation of shared knowledge, through problematizing pedagogical practices that stimulate learning, from the different scenarios of nursing education. It is worth mentioning that pedagogical practice is characterized as the act and political process of (trans)formation, in which there is no neutrality, based on the triangulation of the student's apprehensive action, the educative action of the professor and the programmatic content, in a given pedagogical space-time ${ }^{(18)}$. 
For the training of nurse leaders, it is essential to insert dialogic relationships that enable the active participation of students in their teaching-learning process, as well as stimulate their critical-reflexive positioning. In a perspective that fosters participation and autonomy, the professor assumes a fundamental role in promoting changes in teaching, being a mediator in the teaching-learning process, responsible for strengthening the students' critical and creative thinking, stimulating autonomy. For this, it is relevant to create and use pedagogical spaces that optimize the development of relational skills such as decision making, sensitive listening and communication, which are essential in the formation of leaders.

In the study, the potentials in the teaching of leadership were also indicated by professors: early insertion in practice and the offer of different learning scenarios that enable the development of leadership. According to them, these factors allow the student to grasp the real context of health, which involves the work process of the teams and their leaders, their limitations, challenges, as well as the dynamics of relationships.

In this sense, international research ${ }^{(10,19)}$ emphasizes that nurses need to be prepared to act in all stages of health care and to strengthen their leadership. In the national scenario, studies also reinforce a similar concern ${ }^{(4-5)}$. However, it is emphasized that the training of nurse leaders is a challenge and requires important transformations in the pedagogical practice of nursing professors ${ }^{(11)}$. The need to support these professors is highlighted, so that they can approach the topic more appropriately, in addition to being able to use methodological resources, teaching strategies and foster diverse opportunities for students, which requires both the interest of in its improvement as the support of the higher education institution, investing in the permanent training of its educators.

As for the teaching-learning process, it is necessary to recognize leadership as a managerial competence by students, because when exercising it during academic training, little by little, the student will understand the dimension of the complexity of health services, the scarcity of employees, risks to patient safety, among other experienced problems $s^{(19-21)}$. That said, it is important to promote the previous insertion of nursing student in the practice scenario, in order to provide a critical view of reality, in addition to the recognition of the competencies and skills that need to be developed for this professional performance. This awareness is broadened in the contact with nurses in the care context, during the handling of conflicts specific to the reality of health services at different levels of care.
A study ${ }^{(21)}$ with nursing students evidenced the importance of acquiring skills during the learning process in the clinical environment. The nature of the clinical space is unpredictable and can have an impact on nursing students, including dropping out of the course, as it reveals that students are more vulnerable in this environment and for showing some insecurity due to the lack of relational and communicational skills in the initial semesters. In this sense, the findings indicate the potential transfer to the professor of the responsibility for motivating and contributing to the graduate's self-confidence ${ }^{(21-22)}$. Therefore, it is important to start activities in clinical practice from the first semesters, as a way to stimulate the knowledge to lead.

In this study, in addition to the other potentialities, specific curricular components in the field of health and nursing services management were highlighted, considered key elements in training for leadership. The possibility of expanding the leadership approach in nursing education, through the interlocution of the management discipline with other curricular components, may collaborate for the solidification of the integrated curriculum, based on competences, seeking to break up with traditional models.

The American Association of Colleges of Nursing (AACN) recognized the criticality of leadership development in training spaces. Faced with a reality of change in health services, the shortage of staff and the strong focus on quality care intensify the need to take full advantage of the years of nursing education. Thus, the proposal for a Nursing Leadership Development model emerges, based on the usefulness of the progress of curricular content and educational experiences, starting at the bachelor's level, which sought to expand the leadership capacity of nursing students ${ }^{(23)}$. Both in undergraduate and graduate education, it is important to be clear about the leadership models, considering that they will help teachers in the formation of future leaders ${ }^{(24)}$.

The training of nurse leaders, in addition to being supported by the pedagogical project of the undergraduate Nursing course, needs to articulate the theoretical teaching, its application in practice and the promotion of transformation in the nursing student's social reality. It is understood that nursing professors are examples of leadership for students, therefore, it is healthy to know about leadership models, the managerial skills necessary for leaders and strategies for their implementation, with a view to promoting changes in the training scenario in nursing and health.

In this sense, it is recognized the importance of innovations in theoretical contents of leadership, administration, health management and others for the universe of nursing 
since the competence to lead is an essential component of managerial and clinical practice.

When looking at the teaching of leadership in nursing, Freire's proposal of a pedagogy that fosters critical and transformative participation by the student mediated by the professor ${ }^{(14)}$, enables to strengthen the skills and competences of the nurse leader, opening space for its insertion in different contexts. In the case of the present study, the practice scenarios were valued by the research participants.

In addition, the educator emphasizes leadership among skills that must be developed by liberating professors, who seek to overcome banking education, in addition to group discussions and dynamics ${ }^{(18)}$, which can be considered essential strategies for the formation of leaders, having in view of its ability to promote participation and engagement.

In order to facilitate the development of leaders, professors have adopted active methodologies as tools that enable the improvement of this competence in nursing. This didactic mechanism contributes to the students'autonomy and creativity for decision making, as it is based on the problematics of simulated and real practices ${ }^{(11)}$. The encouragement of active methodologies enables students to have a deeper and more conscious effective learning, through creative dynamics, seminars, pedagogical workshops, laboratory simulations, creative games, films, case studies, among other activities that help the formation of leaders ${ }^{(11,17)}$.

It is worth mentioning, in the perspective proposed by the theoretical framework, the importance of the professor as a facilitator to assist in the development of leadership. However, it must be clear that the roles of the professor and the student are always different, even when practicing democratic relations in class. The liberating professor is different not only because of his formation, but also because he leads a process of transformation that would not occur by itself(11). Based on the above, it can be said that the role of the professor should serve as an example of leadership for the student, encouraging him to experience various learning possibilities during graduation, promoting new challenges and the constant concern with improvement.

Another potentiality that stood out was the participation of students in research groups, corroborating with a previously mentioned study ${ }^{(11)}$. The performance of undergraduate students in research groups has also favored the learning process, as it allows meetings with different levels of education focused on diverse and innovative scientific production and knowledge that enhance the development of skills in the scope of management and leadership. These research groups were considered spaces that promote autonomy, responsibility, commitment and knowledge multipliers, which contribute to the formation of leaders.
The research groups can contribute to liberating actions, which enable the subject to unveil the world and understand his true praxis, through critical reflections that transform his actions ${ }^{(12)}$. Participation in these spaces constitutes a differential in the academic trajectory, in view of the engagement of nursing students in activities that contribute to the development of critical sense, creativity, leadership spirit, autonomy and responsibility. In addition to these spaces mentioned by the professors, it should be added participation in extension projects, Tutorial Education Programs (PET) and academic directories, which are equally relevant to the development of leadership potential.

Thus, considering the results above, it is verified, in the professors' proposals, the use of methodological strategies that facilitate the critical thinking of the students. There is also a concern that both are effectively involved in this educational method that is more coherent with the current context and that gives the student the opportunity to acquire important capabilities to exercise leadership in their actions.

\section{FINAL CONSIDERATIONS}

The research made it possible to understand the perception of nursing professors about the fragilities and potentialities in the training of nurse leaders. The fragilities are found in the difficulties in offering a transversal teaching of leadership, in which this competence could be developed during the training, as well as in educational practices still linked to banking and traditional education.

As potentialities, early insertion in practice was mentioned as a contribution capable of favoring interpersonal relationships, providing students with the ability to develop criticality, to be resolute and able to make decisions, essential elements for the performance of leadership, preparing them for the field of work. In this way, professors invest in learning scenarios and active methodologies that can foster leadership development.

It was also evident that the insertion of the theme during the training process, in the specific curricular components and in the diverse research and extension spaces, can arouse the interest of the student to exercise leadership.

As for the limitations, the study was restricted to investigate the reality of teaching leadership in a public education institution in the State of Bahia, and it is opportune to expand the investigation to verify the fragilities and potentialities experienced by professors in higher education private institutions. Therefore, it is suggested the development of other studies that seek new perspectives on the teaching of leadership, in order to favor the formation of leaders in 
nursing, in addition to portraying the reality of teaching in other states of the country.

The present study sought to foster reflections on the importance of addressing some teaching gaps signaled by professors, through problematizing pedagogical practices, in addition to implementing teaching strategies that enable the training of nurse leaders.

\section{REFERENCES}

1. Amestoy SC, Backes VMS, Thofehrn MB, Martini JG, Meirelles BHS, Trindade LL. Conflict management: challenges experienced by nurse-leaders in the hospital environment. Rev Gaúcha Enferm. 2014;35(2):79-85. doi: https://doi. org/10.1590/1983-1447.2014.02.40155

2. Kodama Y, Fukahori H, Sato K, Nishida T. Is nurse managers' leadership style related to Japanese staff nurses' affective commitment to their hospital? J Nurs Manag. 2016;24(7):884-92. doi: http://doi.wiley.com/10.1111/jonm.12392

3. Hanse JJ, Harlin U, Jarebrant C, Ulin K, Winkel J. The impact of servant leadership dimensions on leader-member exchange among health care professionals. J Nurs Manag. 2016;24(2):228-34. doi: https://doi.org/10.1111/jonm.12304

4. Amestoy SC, Trindade LL, Silva GTR, Santos BP, Reis VRSS, Ferreira VB. Leadership in nursing: from teaching to practice in a hospital environment. Esc Anna Nery. 2017;21(4):e20160276. doi: https://doi. org/10.1590/2177-9465-ean-2016-0276

5. Ferreira VB, Amestoy SC, Silva GTR, Trindade LL, Santos IAR, Varanda PAG. Transformational leadership in nursing practice: challenges and strategies. Rev Bras Enferm. 2020;73(6):e20190364. doi: https://doi. org/10.1590/0034-7167-2019-0364

6. Amestoy SC, Oliveira AFL, Thofehrn MB, Trindade LL, Santos BP, Bao ACP. Contributions of Paulo Freire to understanding the dialogic leadership exercise of nurses in the hospital setting. Rev Gaúcha Enferm. 2017;38(1):e64764. doi: https://doi.org/10.1590/1983-1447.2017.01.64764

7. Miles JM, Scott ES. A new leadership development model for nursing education. J Prof Nurs. 2019;35(1);5-11. doi: https://doi.org/10.1016/j. profnurs.2018.09.009

8. Thusini S, Mingay J. Models of leadership and their implications for nursing practice. British J Nurs. 2019;28(6);356-60. Available from: https://doi. org/10.12968/bjon.2019.28.6.356

9. Stacciarini JMR, Mcdaniel AM. Membrace: developing an inclusive leadership program with and for undergraduate nursing students. J Prof Nurs. 2019;35(1);26-31. doi: https://doi.org/10.1016/j.profnurs.2018.09.001
10. Paterson K, Henderson A, Burmeister E. The impacto of a leadership development programme on nurses'self-perceived leadership capability. J Nurs Manag. 2015;8(23):1086-93. doi: https://doi.org/10.1111/jonm.12257

11. Caveião C, Peres AM, Zagonel IPS, Amestoy SC, Meier MJ. Teachinglearning tendencies and strategies used in the leadership development of nurses. Rev Bras Enferm. 2018;71(suppl 4):1531-9. doi: https://doi. org/10.1590/0034-7167-2017-0455

12. Curtis EA, Sheerin FK, Vries J. Developing leadership in nursing: The impact of education and training. Br J Nurs. 2011;20(4):344,346, 348. doi: https://doi. org/10.12968/bjon.2011.20.6.344

13. Bordin V, Almeida ML, Zilly A, Justino ET, Silva NDV, Faller JW. Liderança em enfermagem na perspectiva de enfermeiros assistenciais de um hospital público da tríplice fronteira. Rev Adm Saúde. 2015;18(71):107. doi: https://doi. org/10.23973/ras.71.107

14. Freire P. Pedagogia do oprimido. 67. ed. Rio de Janeiro: Paz e Terra; 2019.

15. Minayo MCS. 0 desafio do conhecimento: pesquisa qualitativa em saúde. 14 ed. São Paulo: Editora Hucitec; 2014.

16. Neves VR, Sanna MC. Concepts and practices of teaching and exercise of leadership in Nursing. Rev Bras Enferm. 2016;69(4):686-93. doi: https://doi. org/10.1590/0034-7167.2016690417i

17. Towle A. Learning to lead: teaching the millennial nursing student leadership skills in a short-term immersion study abroad program. Int J Nurs Clin Pract. 2015;2:160. doi: https://doi.org/10.15344/2394-4978/2015/160

18. Freire P, Shor I. Medo e ousadia: o cotidiano do professor. São Paulo: Paz e Terra; 2011.

19. Joseph L, Huber DL. Clinical leadership development and education for nurses: prospects and opportunities. J Healthc Leadersh. 2015;7:55-64. doi: https:// doi.org/10.2147/JHL.S68071

20. Coghill Y. When will we see more diverse nursing leadership? Br J Nurs. 2019;28(1):62-3. doi: https://doi.org/10.12968/bjon.2019.28.1.62

21. Ailey H. Educating nursing students in clinical leadership. Nurs Manag (Harrow). 2015;21(9):23-8. doi: https://doi.org/10.7748/nm.21.9.23.e1304

22. Jamshidi N, Molazem Z, Sharif F, Torabizadeh C, Kalyani MN. The challenges of nursing students in the clinical learning environment: a qualitative study. Scient World J. 2016;2016:1846178. doi: https://doi.org/10.1155/2016/1846178

23. Cary A. AACN LEADS: what's in your leadership tool box for volatile, complex times? [editorial]. J Prof Nurs. 2018;35(1):1-2. doi: https://doi.org/10.1016/j. profnurs.2018.12.001

24. Balsanelli AP. Leadership in nursing: challenges and possibilities [editorial]. Acta Paul Enferm. 2017;30(1):3-4. doi: https://doi. org/10.1590/1982-0194201700001 


\section{- Acknowledgments:}

The Universidade Federal da Bahia (UFBA) for the funding of the research, included in the Support Program for Young Professors Doctors (PROPESQ).

\section{- Authorship contribution:}

Conceptualization: Simone Coelho Amestoy, Letícia de Lima Trindade, Gilberto Tadeu Reis da Silva, Patrícia Alves Galhardo Varanda, Ises Adriana Reis dos Santos. Data curation: Simone Coelho Amestoy, Letícia de Lima Trindade, Patrícia Alves Galhardo Varanda, Ises Adriana Reis dos Santos.

Formal analysis: Simone Coelho Amestoy, Letícia de Lima Trindade, Gilberto Tadeu Reis da Silva, Maria Manuela Martins, Patrícia Alves Galhardo Varanda, Ises Adriana Reis dos Santos.

Funding acquisition: Simone Coelho Amestoy. Investigation: Simone Coelho Amestoy, Patrícia Alves Galhardo Varanda, Ises Adriana Reis dos Santos. Methodology: Simone Coelho Amestoy, Patrícia Alves Galhardo Varanda, Ises Adriana Reis dos Santos. Project administration: Simone Coelho Amestoy. Resources: Simone Coelho Amestoy. Software: Simone Coelho Amestoy, Patrícia Alves Galhardo Varanda, Ises Adriana Reis dos Santos. Writing-original draft: Simone Coelho Amestoy, Letícia de Lima Trindade, Gilberto Tadeu Reis da Silva, Maria Manuela Martins, Patrícia Alves Galhardo Varanda, Ises Adriana Reis dos Santos.

Writing-review \& editing: Simone Coelho Amestoy, Letícia de Lima Trindade, Gillberto Tadeu Reis da Silva, Maria Manuela Martins, Patrícia Alves Galhardo Varanda, Ises Adriana Reis dos Santos.

\section{- Corresponding author:}

Simone Coelho Amestoy

Email: simoneamestoy@hotmail.com

\section{Associate editor:}

Dagmar Elaine Kaiser

\section{Editor-in-chief:}

Approved: 01.27.2021
Maria da Graça Oliveira Crossetti 